\title{
Squander Water Treatment Technologies
}

\author{
Aboli V. Chavhan, Arif Khan
}

\begin{abstract}
Constantly 2050 it is foreseen that the Earth's populace will surpass 9 billion. To fulfill the fundamental needs of the populace we'd like innovation to convey secure and safe wellsprings of water for creation of food and vitality. Water repossession, reuse, and reprocess manage these test by resolve water issue moreover make new wellspring of value water arrangements. One among the first testing part of economical manure treatment conspire configuration is that the investigation and choice of the treatment procedures and advances able of social occasion the requirements. This paper audits different innovations of waste water treatment and depicts the strategy for choice of reasonable innovation bolstered certain set up models.
\end{abstract}

Keywords: Waste water; treatment; innovation;

\section{INTRODUCTION}

$\mathrm{O}_{\mathrm{n}}$ ne of the most ubiquitous issues harasses individuals all through the world is insufficient access to clean water and disinfection [1]. Constantly 2050 it is foreseen that the Earth's populace will surpass 9 billion. To fulfill the fundamental needs of the populace we'd like innovation to convey secure and safe wellsprings of water for creation of food and vitality. [2]. Networks over the planet face water gracefully difficulties because of expanding request, dry season, exhaustion and pollution of groundwater, and reliance on single wellsprings of flexibly. Water recovery, reusing, and reuse address these difficulties by settling water asset issues and making new wellsprings of top notch water supplies [3]. There exist various groundbreaking boundaries and hindrance to the broad acknowledgment of water reuse. These comprise of the need for imaginative innovation, innovation pass on, and unique application; the require for open learning and expanded open acknowledgment; need of accessible enrichment for water reuse ventures; and the requirement for continue by pertinent enactments and show. One in the prime requesting part of a practical sewage treatment framework plan is the appraisal and assortment of the treatment procedure and innovations fit for show the necessities. The strategy is to be chosen dependent on required nature of treated water. Other than the expense of treatment, emanating quality, process intricacy, process unwavering quality, natural issues and land necessities ought to likewise be assessed and weighted in choosing the appropriate innovation. This paper is an aggregation of the writing audit directed on different advances of waste water treatment accessible today, and portrays the procedure of choice of reasonable innovation dependent on certain set up rules.

Revised Manuscript Received on August 21, 2020.

* Correspondence Author

Aboli Chavhan*, Department of Environmental Engineering, NCET, Nagpur, India. E-mail: abolichavhan12@gmail.com

Dr. Arif Khan, Principal, NCET, Nagpur, India. E-mail: arif3456@hotmail.com

(C) The Authors. Published by Blue Eyes Intelligence Engineering and Sciences Publication (BEIESP). This is an open access article under the CC BY-NC-ND license (http://creativecommons.org/licenses/by-nc-nd/4.0/)

\section{TECHNOLOGIES OF WASTE WATER TREATMENT}

Squander water treatment is performed by receiving various procedures.

The procedures have been ordered by expulsion of different constituents from squander water. These include expulsion of - natural and inorganic, colloidal and suspended solids, disintegrated natural constituents, and broke down inorganic constituents and organic constituents.

\section{A. Initiated Sludge Process}

Initiated Sludge Process (ISP) is the commonest suspended development process utilized for squander water treatment. During process, squander water contain untreated issue is circulated air through in an air circulation bowl during which small scale creatures use the drifting and solvent natural issue. A piece of natural material is orchestrated into new cells and part is consumed to $\mathrm{CO} 2$ and water to acquire vitality. In enacted slime frameworks the new cells shaped inside the response far away from the fluid stream inside such a woolly muck in settling tanks. An estimation of this settled biomass, clarify as enacted ooze is appearance to the air circulation tank and consequently the suffering structures squander or over muck (Refer Fig. 1)

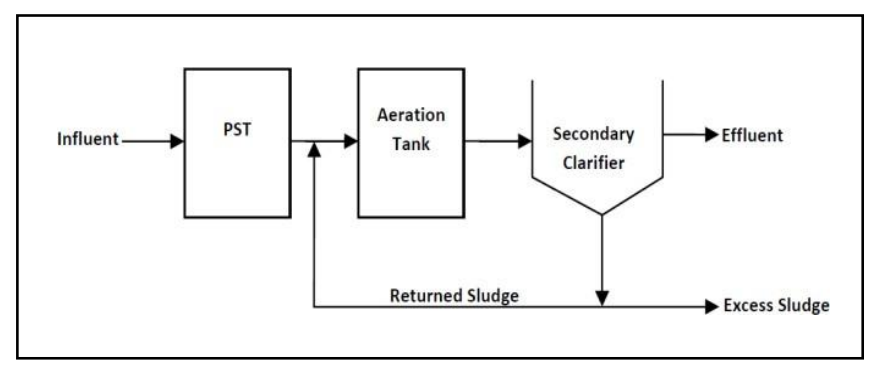

Fig. 1: Schematic of Initiated Sludge Process

Initiated sludge plant includes:

1. Waste water air circulation within the sight of a microbial Suspension

2. Solid-fluid partition following air circulation

3. Discharge of explained emanating

4. Removal of overabundance biomass, and

5. Return of residual biomass to air circulation tank.

It is given essential clarifier to downsize the natural burden in organic reactor (air circulation bowl). About $40 \%$ of natural burden is caught in essential clarifier inside such slime, diminishing the stacking in the air circulation tank. Confinement period in air circulation tank is kept up between 4 to $6 \mathrm{~h}$. After air circulation tank, the blended alcohol is transported to auxiliary explanation where sludge also, fluid are isolated. A genuine bit of the ooze is re-flowed and overabundance is delivered to a digester. In the event that if the muck produced in essential clarifier and abundance ooze from auxiliary clarifier are not developed, processing of such slop is significant before removal.

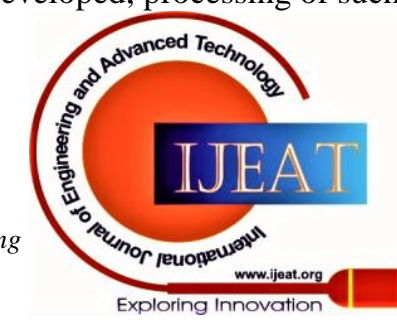




\section{Squander Water Treatment Technologies}

In anaerobic ooze assimilation, such muck produces biogas which might be utilized for power age by gas motors. Produced power is regularly utilized for activity of plant [4].

\section{B. Moving Bed Bio Reactor}

Moving Bed Biofilm Reactor is a vigorous natural development process. It doesn't require essential clarifier and slime distribution. After crude sewage screening and degritting, is taken care of to the organic reactor. Inside the reactor, skimming plastic media is given which stays in suspension. Natural mass expends natural issue for their digestion. Overabundance natural mass leaves the outside of media and settled in clarifier. Typically a detainment season of 5 to $12 \mathrm{~h}$ is given inside the reactors (Refer Fig. 2).

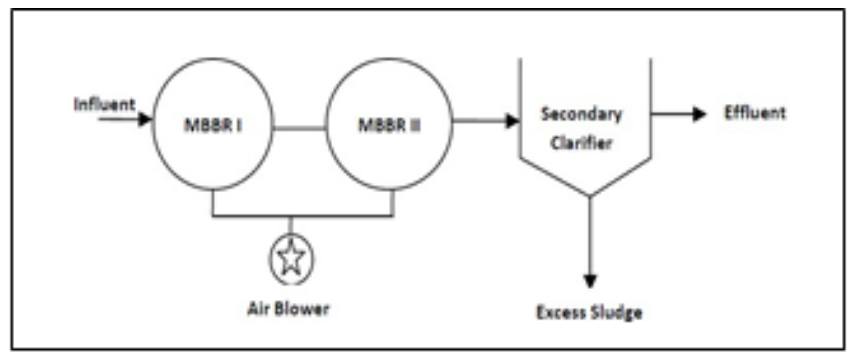

Fig. 2: Schematic of MBBR

MBBR uses the whole tank volume for biomass development. It likewise includes an in reality low head-misfortune. This is frequently accomplished by having the biomass develop on transporters that move openly inside the water volume of the reactor and which are kept inside the reactor volume by a sifter course of action at the reactor outlet. The reactor could even be utilized for oxygen consuming, anoxic or anaerobic procedures [5].

\section{Sequencing Batch Reactor}

Sequencing Batch Reactor (SBR) might be a fill and draw type actuated slime framework. During this strategy squander water is added to a one bunch reactor, treated to dispose of bothersome parts, and afterward released. The conventional actuated muck framework and SBR process are an identical yet the distinction between the two innovations is that the SBR performs balance, organic treatment and auxiliary explanation during a solitary tank utilizing time controlled succession. Adjustment, air circulation, and explanation are frequently accomplished utilizing a solitary group reactor (Refer Fig. 3).

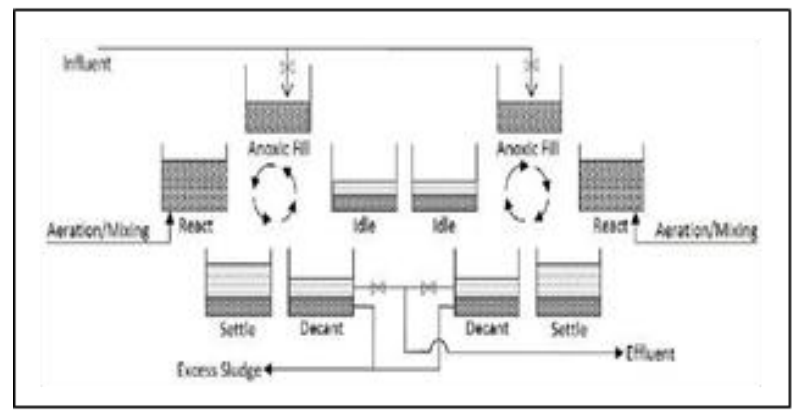

Fig. 3: Schematic of SBR

The successive cluster reactor (SBR) process possibly a cyclic initiated slop treatment process. Sequencing clump reactors will be worked to oxidize carbonaceous BOD, nitrify the alkali and denitrify to diminish absolute nitrogen to a level that meets as far as possible. All treatment forms tallying evening out, air circulation, improvement, and sedimentation and empty happen contained by the SBRs dispose of the commitment for isolated enhancement and return initiated muck frameworks [6].

All the SBR frameworks have five stages, are as follows.

Fill: squander water stream in to the reactor and blend in with the biomass at this point present in the reactor. Filling of influent are regularly fluctuated to make the condition like static fill, blended fill, and circulated air through fill

Respond: Counting on the conditions applied: anaerobic, anoxic or vigorous responses, substrate present in the waste water are devoured by the biomass.

Settle: After adequate season of response, air circulation and blending is halted and biomass is permitted to settle from the fluid prompting clear supernatant.

Tap: Clear supernatant (treated waste water) is far away from the reactor.

Inert: This is frequently the time between cycles which are utilized to compose the SBR for next cycle. It is likewise important to alter the process duration between the SBR reactors. Slop squandering is furthermore performed during this stage.

\section{Up-stream Anaerobic Sludge Blanket}

These days, carbon emanation and carbon impression of water utilities is a critical issue. High-rate anaerobic digesters acknowledge incredible advantage because of their high burden limit and low slime creation. Among them, the upstream anaerobic ooze cover reactors have been most commonly utilized [7]. UASB is an anaerobic movement during which influent waste water is dispersed at the absolute bottom of the reactor and goes in an up-stream mode through the slime cover conveyance structure, GLSS and drainage taking out plan contrast with other anaerobic procedure, UASB permit the utilization of high water powered stacking (Refer Fig. 4).

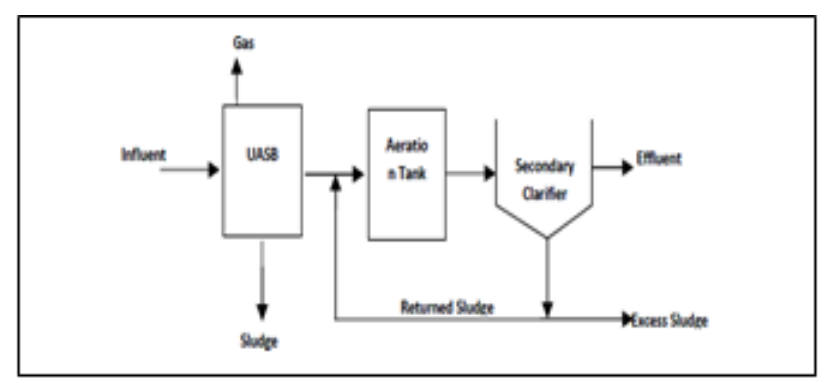

Fig. 4: Schematic of UASB

\section{E. Membrane Bio Reactor}

Film bioreactor (MBR) innovation, which blend organic initiated muck technique and layer filtration has gotten more respected, lavish, and acknowledged as of late for the treatment of such wastewaters, though the customary enacted slime process can't manage either creation of wastewater or vacillations of wastewater stream. MBR innovation is moreover used in situations where request on head of the norm of profluent surpasses the capability of CAS. Though MBR reserves and prepared costs go above unsurprising procedure, it appear that the raise of unsurprising movement happen even in situations when unadventurous administration functions admirably. It is regularly related with increment of water cost and requirement for water reuse additionally like more tough guidelines on the profluent quality.

Published By:

Blue Eyes Intelligence Engineering

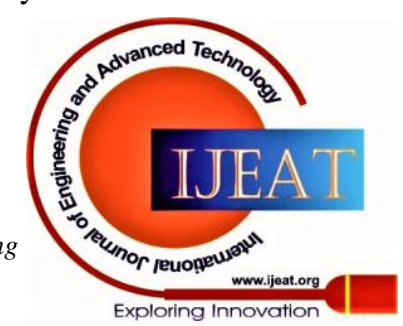


Nearby better comprehension of developing contaminants in wastewater, their biodegradability, and with their consideration in new guidelines, MBR may turn into a fundamental redesign of existing innovation in order to fulfill the legitimate prerequisites in wastewater treatment plants (WWTPs) [8]. Layer Bio Reactors (LBR) for squander water treatment is might be a mix of a suspended development organic treatment strategy, generally actuated slime, with film filtration gear, ordinarily low-pressure microfiltration (MF) or ultra-filtration (UF) layers. The films are needed to play out the basic strong fluid partition work. In enacted slop offices, this is regularly customarily achieved utilizing auxiliary and tertiary clarifiers alongside tertiary filtration. The strong fluid partition in layer bioreactor is accomplished by a microfiltration film with pore sizes beginning from 0.1 to 1.0 $\mu \mathrm{m}$. No optional clarifier is utilized and has the office to figure at high MLSS fixations. (Refer Fig. 5)

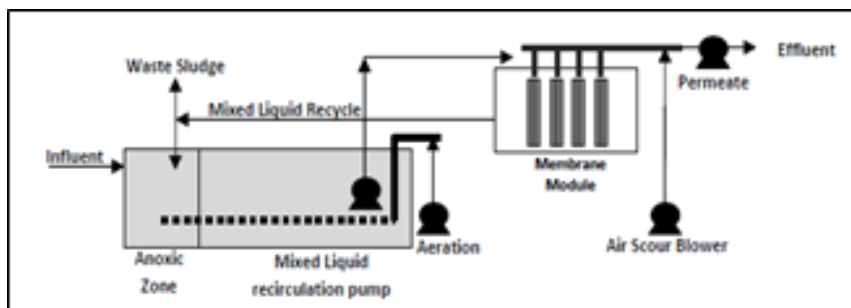

Fig.5: Schematic of MBR

\section{COMPARATIVE ANALYSIS OF TECHNOLOGIES}

During the time spent choosing the first reasonable innovation, it is important to coordinate various highlights of the advances likewise their presentation. The accompanying (Table I) give the noteworthy thought for collection of waste water taking care of procedures. The resulting (Table II) give a relative examination of the advances that were portrayed in the past segment.

Table I: Sewage Treatment Process Selection Consideration

\begin{tabular}{|l|l|}
\hline \multicolumn{1}{|c|}{ Consideration } & \multicolumn{1}{c|}{ Goal } \\
\hline Quality of treat Sewage & $\begin{array}{l}\text { Manufacture of } \\
\text { treated water of } \\
\text { predetermined value } \\
\text { without stoppage }\end{array}$ \\
\hline Power requirement & $\begin{array}{l}\text { Reduce energy } \\
\text { consumption }\end{array}$ \\
\hline Land required & Minimize land requirement \\
\hline Capital Cost of Plant & $\begin{array}{l}\text { Optimum utilization of } \\
\text { capital }\end{array}$ \\
\hline $\begin{array}{l}\text { Operation \& Maintenance } \\
\text { costs }\end{array}$ & $\begin{array}{l}\text { Lower recurring } \\
\text { expenditure }\end{array}$ \\
\hline Maintenance requirement & Simple and reliable \\
\hline Operator attention & Easy to know procedures \\
\hline Reliability & $\begin{array}{l}\text { Consistent delivery } \\
\text { of treated sewage }\end{array}$ \\
\hline Resource Recovery & $\begin{array}{l}\text { Production of quality } \\
\text { water and manure }\end{array}$ \\
\hline Load Fluctuations & $\begin{array}{l}\text { With stand variations in } \\
\text { organic and hydraulic } \\
\text { loads }\end{array}$ \\
\hline
\end{tabular}

Table II: Comparison Of Devastate Water Treatment Technology In Provisions Of Significant Parameter

\begin{tabular}{|c|c|c|c|c|c|}
\hline $\begin{array}{l}\text { Paramet } \\
\text { er }\end{array}$ & ASP & $\begin{array}{l}\text { MBB } \\
\mathbf{R}\end{array}$ & SBR & $\begin{array}{l}\text { UAS } \\
\text { B }\end{array}$ & $\begin{array}{l}\text { MB } \\
\mathbf{R}\end{array}$ \\
\hline $\begin{array}{l}\text { BOD, } \\
\mathrm{mg} / \mathrm{l}\end{array}$ & $<30$ & $\begin{array}{l}<20-3 \\
0\end{array}$ & $<5$ & $<30$ & $\begin{array}{l}<3-< \\
5\end{array}$ \\
\hline $\begin{array}{l}\text { COD, } \\
\mathrm{mg} / \mathrm{l}\end{array}$ & $<250$ & $<250$ & $<100$ & $<250$ & $<100$ \\
\hline TSS, mg/l & $<100$ & $<100$ & $<10$ & $<100$ & $<5$ \\
\hline $\begin{array}{l}\text { TKN \&P } \\
\mathrm{mg} / \mathrm{l}\end{array}$ & $\mathrm{NT}^{*}$ & $\mathrm{NT}^{*}$ & $\begin{array}{l}<10- \\
<2\end{array}$ & $\mathrm{NT}^{*}$ & $\mathrm{NT}^{*}$ \\
\hline $\begin{array}{l}\text { Area, } \\
\text { Acres }\end{array}$ & 10.9 & 5.5 & 6.3 & 15.6 & 5 \\
\hline $\begin{array}{l}\text { Capital } \\
\text { Cost Rs. } \\
\text { Lac } \\
\text { (100ML } \\
\text { D) }\end{array}$ & 6000 & 7000 & 8000 & 6500 & $\begin{array}{l}2500 \\
0\end{array}$ \\
\hline $\begin{array}{c}\text { Power } \\
\text { cost } \\
\text { Rs/m3 }\end{array}$ & 1.71 & 1.8 & 1.14 & 1.11 & 3.0 \\
\hline $\begin{array}{l}\text { Chemical } \\
\text { Cost }\end{array}$ & 0.07 & 0.07 & 0.06 & 0.07 & 0.50 \\
\hline $\begin{array}{l}\text { Main } \\
\text { cost } \\
\text { Rs./m3 }\end{array}$ & 0.22 & 0.25 & 0.27 & 0.22 & 1.1 \\
\hline
\end{tabular}

A complete investigation depicting the positive parts of the most significant elements is performed to get the accompanying outcome as given in Table III [9].

Tabl III: Technology Assessment for Sewage Treatment

\begin{tabular}{|c|l|l|l|l|l|}
\hline Criteria & ASP & MBBR & SBR & UASB & MBR \\
\hline $\begin{array}{c}\text { Quality of } \\
\text { Treated Effluent }\end{array}$ & & & & & \\
\hline $\begin{array}{c}\text { Nutrient } \\
\text { Removal } \\
\text { potential }\end{array}$ & & & & \\
\hline $\begin{array}{c}\text { Low Land } \\
\text { Requirement } \\
\text { potential }\end{array}$ & & & & \\
\hline $\begin{array}{c}\text { Low Capital Cost } \\
\text { potential }\end{array}$ & & & \\
\hline $\begin{array}{c}\text { Low Power } \\
\text { Requirement } \\
\text { Potential }\end{array}$ & & & & \\
\hline $\begin{array}{c}\text { Electricity } \\
\text { generation } \\
\text { potential }\end{array}$ & & & \\
\hline Low O \& M & & & \\
Skills Potential & & & & \\
\hline & & & \\
\hline Low & & & \\
\hline
\end{tabular}

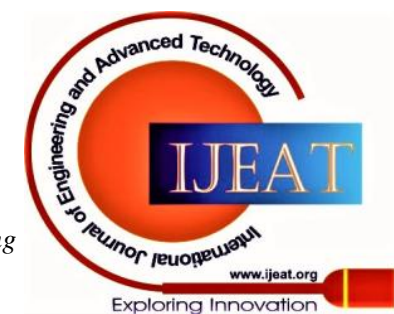




\section{Squander Water Treatment Technologies}

\section{SELECTION OF TECHNOLOGY}

Arrangement of hardware for attack water treatment relies on the resulting boundary:

1. The use to be finished of treat leakage

2. Nature of waste water

3. Compatibility of treatment process

4. Available methods for extreme removal of contaminant

5. Environmental and financial achievability

The utilize of treat squander matter, for eg. For drinking or cooking, request the degree of the board required to be extremely high, with the goal that suchlike constituent's current in the plan should be separated. The character of waste water alludes to the qualities of the influent that progressively relies upon the constituents inside the waste water or its degree of defilement. Similarity of treatment process alludes to the reasonableness of a procedure for a particular situation or specific kind of waste water. So also the accessible methods for extreme removal of contaminants is likewise significant since huge numbers of treatment innovation produce some optional contaminations which need further consideration for their protected removal. The natural achievability alludes to the effect of a specific innovation on the earth regarding the contamination that it makes during its activity or because of the capacity or removal of the created squander.

\section{CONCLUSION}

Water reuse and recover has been famous as an info come quite close to improve water deficiency. It is comprehended that one fourth of worldwide populace faces financial water shortage came about because of helpless administration of the adequate accessible water assets. Subsequently appropriate management in water reusing and reprocess is required to give the best answer for water fiasco. It is in this way required to utilize propelled squander water treatment strategies which would essentially improve the presentation of treatment plants and the creation of top notch emanating reasonable for different reuse applications. Different cutting edge innovations, for example, ASP, MBBR, SBR, MBR and UASB have been examined and an examination of these techniques as far as their presentation to accomplish certain standards has been introduced. Serving the total populace with sufficient drinking water and disinfection is a significant essential, not exclusively to sterile security, yet in addition to success. Thus to fulfill the essential needs of the populace which is foreseen to be in excess of 9 billion continuously 2050, innovative headway in water reusing and reuse which can most likely convey secure and safe wellsprings of water for creation of food and vitality, is fast approaching.

\section{REFERENCES}

1. Mark A Shannon, "Science with innovation professional water cleaning inside the moving toward decades", World Scientific Publishing Co., 2009, pp.337-346.

2. John W.Finley, James N.Seiber, SatinderAhuja, "The Need for Water Reuse", Food Energy and Water, 2015, pp. 431-447.

3. G. Swim Miller, "Joined Concepts in Water Reuse: Managing Global Stream Needs", Desalination, 2006, pp. 67-75

4. Vinod Tare, "Sewage Treatment in Class I Towns: Recommendations and Guidelines", Report (Code 003-GBP-IIT-EQP-S\&R-O2-Ver1), 2010.

5. H Shailaja, "Feasibility Report on Sewage Treatment Plant", Unpublished Report.
6. S Chong, T K Sen, A Kayaalp and H M Ang, "The Performance Enhancement of Upstream Anaerobic Sludge Blanket Reactors for Domestic Sludge Treatment - A State of the Art Review", Water Research, Vol. 46, Issue 11, 2012, pp 3434-3470.

7. Jelena Radjenovi et al, "Film Bioreactor (MBR) as a higher Wastewater Management Technology", Environmental Chemistry, Vol 5, 2008, pp37-110.

8. Vinita Dhupkar, "Streamlining of Design and Technology for Sewage Treatment", National Conference on Energy and Environment, February, 2014.

\section{AUTHORS PROFILE}

Aboli Chavhan Department of Environmental Engineering, NCET, Nagpur, India abolichavhan12@gmail.com

Dr. Arif Khan Principal, NCET, Nagpur, India arif3456@hotmail.com

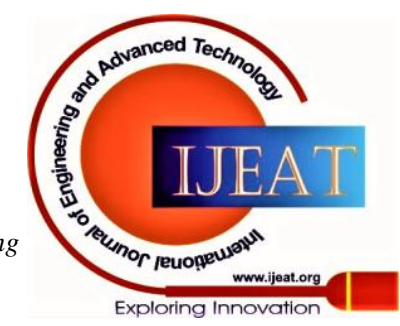

